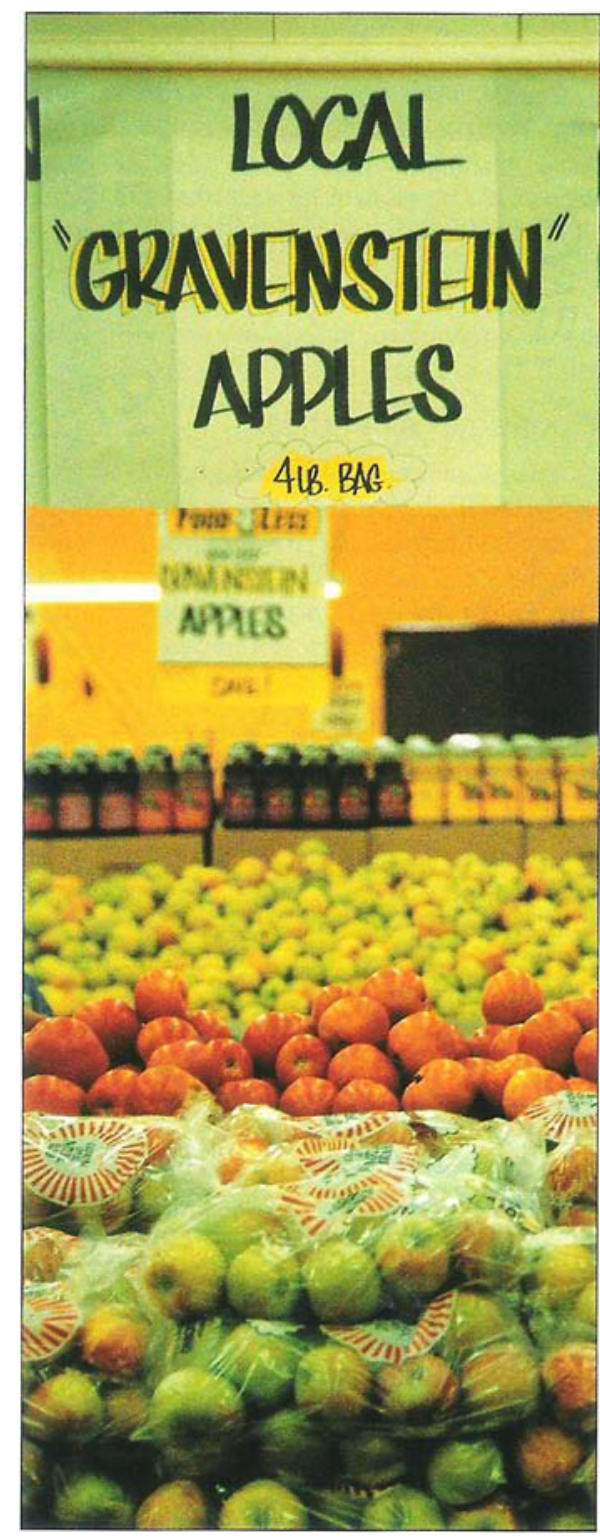

Surveyed shoppers preferred to buy produce labeled as "local," but were unwilling to pay more for it.

\section{Can small farmers in California achieve greater profits through promotion of "locally grown" pro- duce? Interviews and sales data in- dicate that consumers are attracted to locally grown produce, but not if the quality is poor or the price is more than they are used to spend- ing. When markets advertise high- quality, locally grown produce at a fair price, produce sales increase.}

\title{
Consumer attitudes toward locally grown produce
}

\author{
Christine M. Bruhn \\ a Paul M. Vossen \\ 口 Erin Chapman \\ Suzanne Vaupel
}

Locally grown produce has attracted consumers to certified farmers' markets throughout the nation. In California, farmers' markets account for less than $1 \%$ of produce sales. As consumers express a greater willingness to buy flavorful, fresh produce, small farmers may find another outlet for their wares: local grocery stores. By selling directly to supermarkets, farmers can receive prices higher than wholesale. The resulting enhancement in their economic viability may make them better able to resist development pressures and to stay in farming.

Locally grown produce has the potential for very high quality because it can be harvested when fully ripe. With minimum shipping, it can arrive at market shortly after harvest, and if held at the proper temperature it will have little loss in nutritive value. Furthermore, fresh-to-market produce often tastes better than produce that has traveled through the conventional marketing system. In 1982, Robert Sommer, Margot Stumpf, and Henry Bennett conducted a double-blind taste test contrasting supermarket and farmers' market produce; consumers preferred the farmers' market produce, which the researchers concluded was more likely to be locally grown.

According to two previous studies, the desire for flavorful, fresh, locally grown produce is the primary reason consumers give for shopping at farmers' markets, but another researcher found the markets' inconvenient locations and hours (usually only daylight) prevent consumers from using them more often. If locally grown produce were available and in demand in major supermarkets, total sales volume for local farmers could increase. With more outlets in the form of supermarkets and farmers' markets available, small farms, which constitute the majority of farms selling at local farmers' markets, would benefit economically.

According to previously published surveys, consumers nationwide say that in se- lecting produce they care more about its quality, appearance, and nutritive value than where it was grown. The desire to support local producers was of minor importance to consumers. They did, however, view locally grown products positively, expecting them to be fresher than crops grown further away, and of equal or better quality. Consumers, for example, frequently mentioned a preference for locally grown tomatoes, but actual market behavior has not demonstrated that signs identifying produce as locally grown can by themselves increase sales.

This project assessed consumer interest in locally grown produce sold in major supermarkets in two California communities. We expect California consumers to perceive freshness and quality as the most important attributes of locally grown produce. Also, environmental legislation and voter initiatives in California suggest that consumers here may be more sensitive to the needs of agriculture, especially local agriculture, than consumers in other states. A primary goal of this study was to obtain data supporting the idea that consumer interest in obtaining local grown produce will generate a response from supermarket management.

\section{The survey sample}

In May and June 1989, 400 consumers were interviewed: 200 in the produce section of an independent supermarket chain in Sacramento and 100 each at a discount supermarket and at a national chain supermarket in Sonoma. The supermarkets primarily serve a middle-income Caucasian clientele. This was an exploratory study, so its scope was somewhat limited. Results can be project to other markets of similar demographics, but not beyond.

At each site, half of the interviews took place on weekdays between 9 A.M. and 5 P.M., and half took place on the weekend. Interviewers approached each person entering the produce department until the required number of interviews had been 


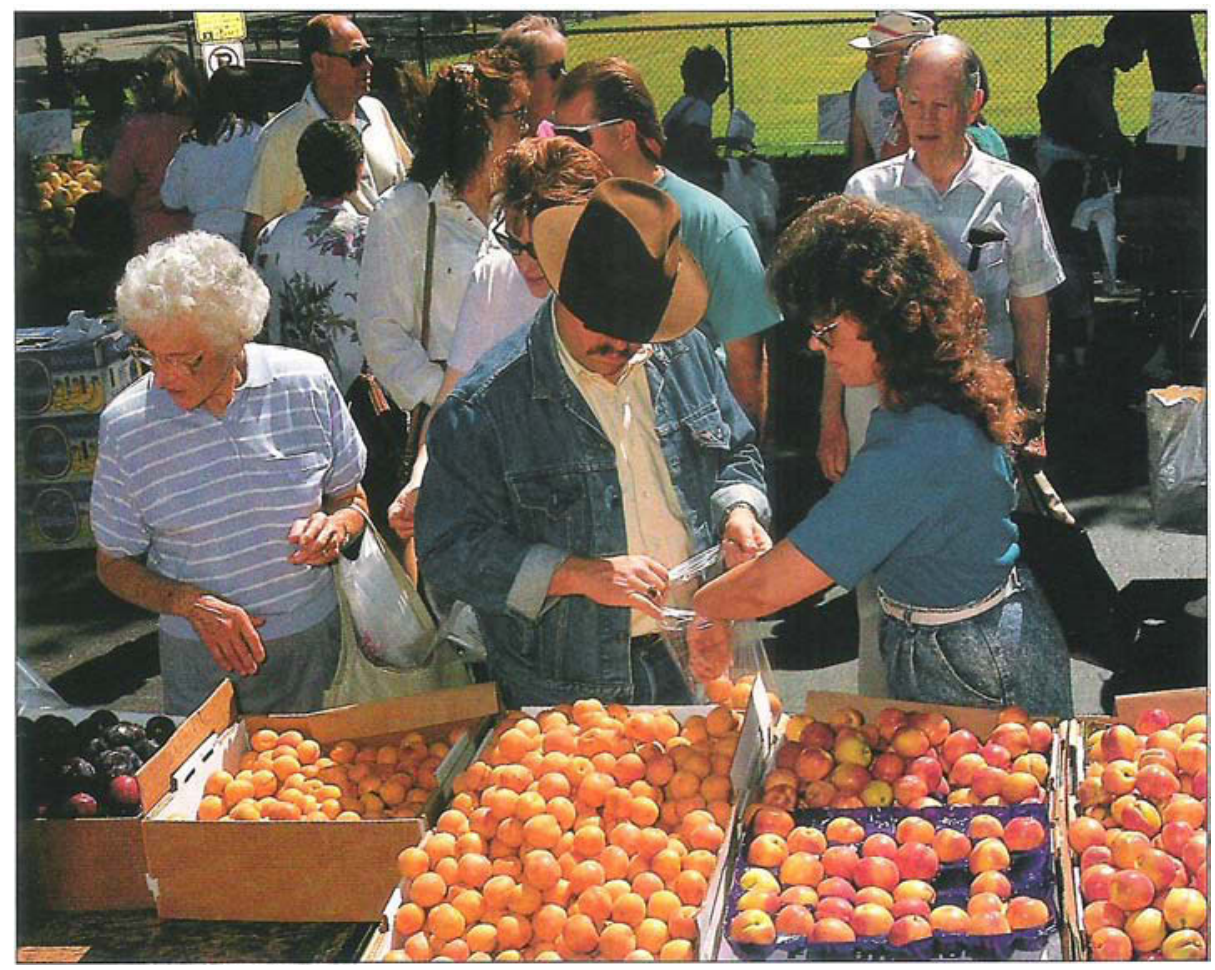

completed. Consumers were asked to list in their own words what they liked about their supermarkets, what influenced their choices in the produce section, and what they thought of locally grown produce.

After all interviews were completed, two supermarkets conducted a test to measure whether sales volume was affected when locally grown produce was specifically identified.

Two-thirds of those interviewed were female. Age was evenly distributed in the sample; approximately one-third were in their 30s. Eighty percent of the respondents were employed outside the home; employment was highest among consumers at the independent market. Forty percent of those questioned had teenagers or young children at home.

Of the independent supermarket's customers that we interviewed, approximately one-third had annual incomes of more than $\$ 50,000$. Approximately onethird of the discount supermarket's interviewees had annual incomes below $\$ 20,000$. Upper and lower income respondents were approximately even at the national chain (table 1).

\section{Responses}

Each supermarket had distinctive features that attracted customers (table 2). The independent supermarket was noted for its convenient location (33\%), the quality of its produce $(24 \%)$, the variety of products available (22\%), the cleanliness of the store (20\%), and the helpfulness of the clerks (19\%). The discount supermarket was selected for its low prices $(87 \%)$ and the variety of products available (24\%). Convenience of location $(53 \%)$ and quality of produce ( $16 \%$ ) were features that distinguished the national chain market from its competitors.

Consistent with regional and national surveys, flavor, nutritive values, and appearance were the biggest influences in produce selection (table 3). Price was listed fourth in importance, but was more important to consumers frequenting the discount supermarket $(58 \%)$ ) than to those shopping at the independent store (28\%) and at the chain (48\%). Whether produce was organic or locally grown was considered important by $22 \%$ of the total sample, but a breakdown of the sample shows wide variations in percentages. People interested in organic produce also expressed interest in locally grown items. Interest in locally grown produce was not related to age, gender, income, ethnicity, employment status, or number of children. Locally grown was considered not important by $43 \%$ of the sample.
Direct-marketed, locally grown produce draws crowds of shoppers to farmers' markets up and down California.

\section{Consumer awareness}

Consumers displayed limited awareness of the availability of locally grown produce. The independent chain and the discount store specifically advertise locally grown produce, and each store offers some produce signed as locally grown. Despite this, fewer than half of consumers could recall the availability of locally of grown produce. Recall was greater among

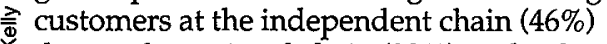
than at the national chain $(39 \%)$ or the dis-

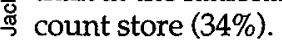

The majority of consumers voiced advantages to purchasing locally grown produce; only $14 \%$ could find no advantage. Consumers volunteered that purchasing locally grown produce supports local agriculture $(41 \%)$, provides fresher produce ( $38 \%)$, and offers products of high quality (11\%) (table 4). Few consumers in our survey mentioned improved nutrition and better flavor as advantages. Most (78\%) could see no disadvantage to purchasing locally grown produce; 3 to $5 \%$ mentioned inadequate supplies, short seasons, or lower quality as potential disadvantages.

Consumer perception of advantages varied at each supermarket. Shoppers at the national chain were more cognizant of support for local agriculture. Those shopping at the discount supermarket mentioned produce quality more often than did customers at the other markets.

For equally convenient stores, about half of the customers at the discount supermarket and half at the national chain

\begin{tabular}{|c|c|c|c|c|}
\hline \multirow[t]{2}{*}{ Characteristic } & $\begin{array}{l}\text { Supermarket: } \\
\text { i..dependent } \\
(n=200)\end{array}$ & $\begin{array}{l}\text { Supermarket: } \\
\text { discount } \\
(n=100)\end{array}$ & $\begin{array}{l}\text { Supermarket: } \\
\text { national chain } \\
\qquad(n=100)\end{array}$ & $\begin{array}{c}\text { Total } \\
(n=400)\end{array}$ \\
\hline & \multicolumn{4}{|c|}{ 다 } \\
\hline Gender: female & 64 & 66 & 72 & 66 \\
\hline Employed outside home & 87 & 68 & 77 & 80 \\
\hline Chidren at home & 37 & 50 & 49 & 43 \\
\hline \multicolumn{5}{|l|}{ Age group: } \\
\hline under 20 & 1 & 2 & 1 & 1 \\
\hline $20-29$ & 18 & 16 & 21 & 18 \\
\hline $30-39$ & 40 & 35 & 30 & 36 \\
\hline $40 \quad 49$ & 21 & 16 & 22 & 20 \\
\hline $50-59$ & 11 & 16 & 9 & 12 \\
\hline 60 plus & 10 & 14 & 17 & 13 \\
\hline \multicolumn{5}{|l|}{ Family income (gross): } \\
\hline less than $\$ 20.000 / y r$ & 8 & 29 & 23 & 16 \\
\hline $520,000-\$ 49,000 / y r$ & 50 & 50 & 51 & 50 \\
\hline more than $\$ 50.000 \mathrm{yr}$ & 35 & 14 & 25 & 28 \\
\hline prefer noi lo answer & 7 & 3 & 0 & 4 \\
\hline
\end{tabular}


indicated the availability of locally grown produce would have a major impact on store selection. This suggests that the availability of labeled "locally grown" produce could be an effective marketing tool. Availability of locally grown produce was more important to older customers than to younger ones $(r=.10)$.

In Sacramento, a wide variety of locally grown items is available; in Sonoma, selection is more limited. Almost all consumers said they were buying some locally grown produce now; in Sonoma, however, about $25 \%$ of the consumers erroneously listed produce not grown in the area. This finding is consistent with other studies that have found consumers have little knowledge of where fruits and vegetables originate and cannot identify in-state and outof-state products.

Consumers identified apples, corn, lettuce, asparagus, strawberries, melons, and pears as locally grown items they often purchase. More than 100 consumers said they would like to purchase as many locally grown fresh products as possible. Tomatoes, corn, and grapes were mentioned most frequently as locally grown items not available in sufficient quantities.

Almost half of the consumers expected to pay less for locally grown produce, primarily because less shipping is involved (table 4); $37 \%$ expected to pay the same amount for locally grown produce, and only $13 \%$ expected to pay a premium. Customers were specifically asked if they would pay 5 to 20 cents more for locally grown corn, peaches, tomatoes, or greens (table 5). Forty-five to 50\% of the people interviewed said they would pay no more for these items. Greatest interest was in the purchase of locally grown tomatoes, with $26 \%$ of the discount market sample indicating they would pay 15 to 20 cents more per pound for them.

Expressed interest in buying locally grown produce does not always reflect actual buying behavior by consumers. To gauge their responsiveness to products advertised as locally grown, two of the participating supermarkets noted sales volume of produce from conventional produce brokers compared with locally grown produce identified by in-store signs. In an actual market situation, it is difficult to control quality, and prices are not held constant because special buys are passed on to the consumer as lower prices. In Sonoma, tests with signs took place during the county fair, a time when produce sales traditionally fall. Therefore, a completely controlled test of the influence of signs identifying locally grown products was impossible to achieve. Nevertheless, trends in purchase behavior were noted (table 6). In three products, where quality of local produce was equal to or
TABLE 2. Features surveyed consumers like about supermarkets (volunteered)

\begin{tabular}{|c|c|c|c|}
\hline Features & $\begin{array}{l}\text { Supermarket: } \\
\text { independent } \\
\qquad(n=200)\end{array}$ & $\begin{array}{l}\text { Supermarket: } \\
\text { discount } \\
(n=100)\end{array}$ & $\begin{array}{l}\text { Supermarket: } \\
\text { national chain } \\
\qquad(n=100)\end{array}$ \\
\hline \multicolumn{4}{|c|}{ 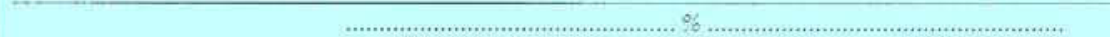 } \\
\hline Convenient location & 33 & 8 & 53 \\
\hline Quality produce & 24 & 7 & 16 \\
\hline Product variety & 22 & 24 & 11 \\
\hline Clean store & 20 & 1 & 1 \\
\hline Low prices & 3 & 87 & 2 \\
\hline Helpful clerks & 19 & 0 & 8 \\
\hline Quality meats & 7 & 2 & 7 \\
\hline Locally grown produce & 1 & 6 & 2 \\
\hline Know location of products & 6 & 4 & 3 \\
\hline Long hours & 1 & 2 & 2 \\
\hline
\end{tabular}

\begin{tabular}{|c|c|c|c|c|}
\hline Characteristic & $\begin{array}{l}\text { Supermarket: } \\
\text { independent } \\
(n=200)\end{array}$ & $\begin{array}{l}\text { Supermarket: } \\
\text { discount } \\
(n=100)\end{array}$ & $\begin{array}{l}\text { Supermarket: } \\
\text { national chain } \\
\qquad(n=100)\end{array}$ & $\begin{array}{c}\text { Total } \\
(\mathrm{n}=400)\end{array}$ \\
\hline \multicolumn{5}{|c|}{ 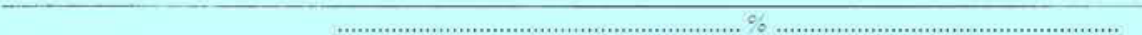 } \\
\hline Flavor/taste & 64 & 82 & 69 & 70 \\
\hline Nutritional value & 48 & 63 & 57 & 54 \\
\hline Appearance & 50 & 49 & 41 & 48 \\
\hline Price & 28 & 58 & 48 & 38 \\
\hline Locally grown & 12 & 36 & 29 & 22 \\
\hline Organically grown & 16 & 23 & 22 & 19 \\
\hline Recipes & 3 & 4 & 12 & 6 \\
\hline \multicolumn{5}{|c|}{ TABLE 4. Consumer perception of locally grown produce } \\
\hline Perception & $\begin{array}{l}\text { Supermarket: } \\
\text { independent } \\
(n=200)\end{array}$ & $\begin{array}{l}\text { Supermarket: } \\
\text { discount } \\
(n=100)\end{array}$ & $\begin{array}{l}\text { Supermarket: } \\
\text { national chain } \\
(n=100)\end{array}$ & $\begin{array}{c}\text { Total } \\
(n=400)\end{array}$ \\
\hline \multicolumn{5}{|c|}{ Advantages of locally grown (volunteered): } \\
\hline Support local agriculture & 31 & 47 & 56 & $41^{\circ}$ \\
\hline Fresher produco & 40 & 44 & 29 & 38 \\
\hline Higher quality & 7 & 22 & 9 & $11^{*}$ \\
\hline More nutritious & 1. & 1 & 2 & 1 \\
\hline Better flavor & 1 & 7 & 1 & $3+$ \\
\hline \multicolumn{5}{|l|}{ Price expectations: } \\
\hline Expect to pay less & 57 & 41 & 36 & 48 \\
\hline Expect to pay same & 37 & 36 & 40 & 37 \\
\hline Expect to pay more & 5 & 21 & 23 & 13 \\
\hline Don't know & 1 & 2 & 1 & 2 \\
\hline \multicolumn{5}{|c|}{$\begin{array}{l}\text { For equally convenient stores. } \\
\text { percent noting that availability } \\
\text { of locally grown produce } \\
\text { would have major impact }\end{array}$} \\
\hline on store selection:" & 34 & 49 & 50 & 42 \\
\hline
\end{tabular}

-Significant difference between stores at $p<001$.

†Significant difference between stores at $p<01$.

TABLE 5. Percentage of customers willing to pay 15 to 20 cents more per unit for locally grown produce

\begin{tabular}{|c|c|c|c|c|}
\hline Produce & $\begin{array}{l}\text { Supermarket: } \\
\text { independent } \\
(n=200)\end{array}$ & $\begin{array}{l}\text { Supermarket: } \\
\text { discount } \\
(n=100)\end{array}$ & $\begin{array}{l}\text { Supermarket: } \\
\text { national chain } \\
\qquad(n=100)\end{array}$ & $\begin{array}{c}\text { Total } \\
(n=400)\end{array}$ \\
\hline Corn (por car) & 7 & 9 & 14 & 10 \\
\hline Peaches (per pound) & 9 & 15 & 16 & 12 \\
\hline Greens (per bunch) & 8 & 12 & 17 & 12 \\
\hline Tomatoes (per pound) & 12 & 26 & 19 & 17 \\
\hline
\end{tabular}

TABLE 6. Market performance of products labeled "locally grown"

\begin{tabular}{|c|c|c|c|}
\hline & Quality & Price & Sales \\
\hline \multicolumn{4}{|l|}{ Independent chain } \\
\hline Chard & same & same & $150 \%$ increase \\
\hline Radishes & lower & same & $30 \%$ decrease \\
\hline Cherries & higher & lower & $400 \%$ increase \\
\hline Asparagus & same & same & $160 \%$ increase \\
\hline \multicolumn{4}{|l|}{ Discount markot } \\
\hline Mushrooms & unknown & same & $35 \%$ decrease \\
\hline Italian squash & unknown & same & $95 \%$ increase \\
\hline
\end{tabular}


better than the product normally offered, sales increased; in a fourth product, where quality was lower, sales fell. These results suggest that when locally grown quality is good, signing can increase sales, but locally grown designations will not compensate for lower quality.

\section{Implications}

Although California consumers at the two study sites believe that purchasing locally grown products supports local agriculture and provides a fresher product, they do not actively seek them. When locally grown products, identified by sign, are of high quality, sales can increase.

Large supermarkets are less able to market produce from small local farmers because the quantity produced may not be adequate, and quality, packaging, and supply may be inconsistent. Smaller supermarket chains and independents, however, can benefit from the positive aura of "locally grown." Consumers view locally grown produce as fresher, and recognize the positive impact on the local economy. Thus, supermarkets advertising locally grown produce can be viewed as both supporting the community and providing high-quality produce for customers. It is imperative, however, that the local produce be of good quality. Consumers are attracted to locally grown items, but not at the expense of quality and price. Supermarkets should not plan to charge more for locally grown items. Consumers expect them to be cheaper or the same price.

Some consumers can correctly name locally grown produce, but others cannot identify which crops are grown locally. Therefore, organizers of promotion campaigns should not assume consumers are knowledgeable about local produce and should include explicit identification.

Because relatively few customers appear to be aware that their supermarket features locally grown items, more aggressive advertising programs would be appropriate. Development and promotion of a locally grown logo could increase awareness. If items identified as locally grown are always of good quality, the perception of consumers that locally grown is fresher will grow, thereby enhancing demand for locally grown produce.

More research is needed to fully describe consumer response to locally grown items when price and quality difference are controlled.

C. M. Bruhn is Extension Specialist, Food Science and Technology, UC Davis; P. M. Vossen is Cooperative Extension Farm Advisor, Sonoma County; $E$. Chapman was formerly with the UC Small Farm Center; and S. Vaupel is an independent consultant.

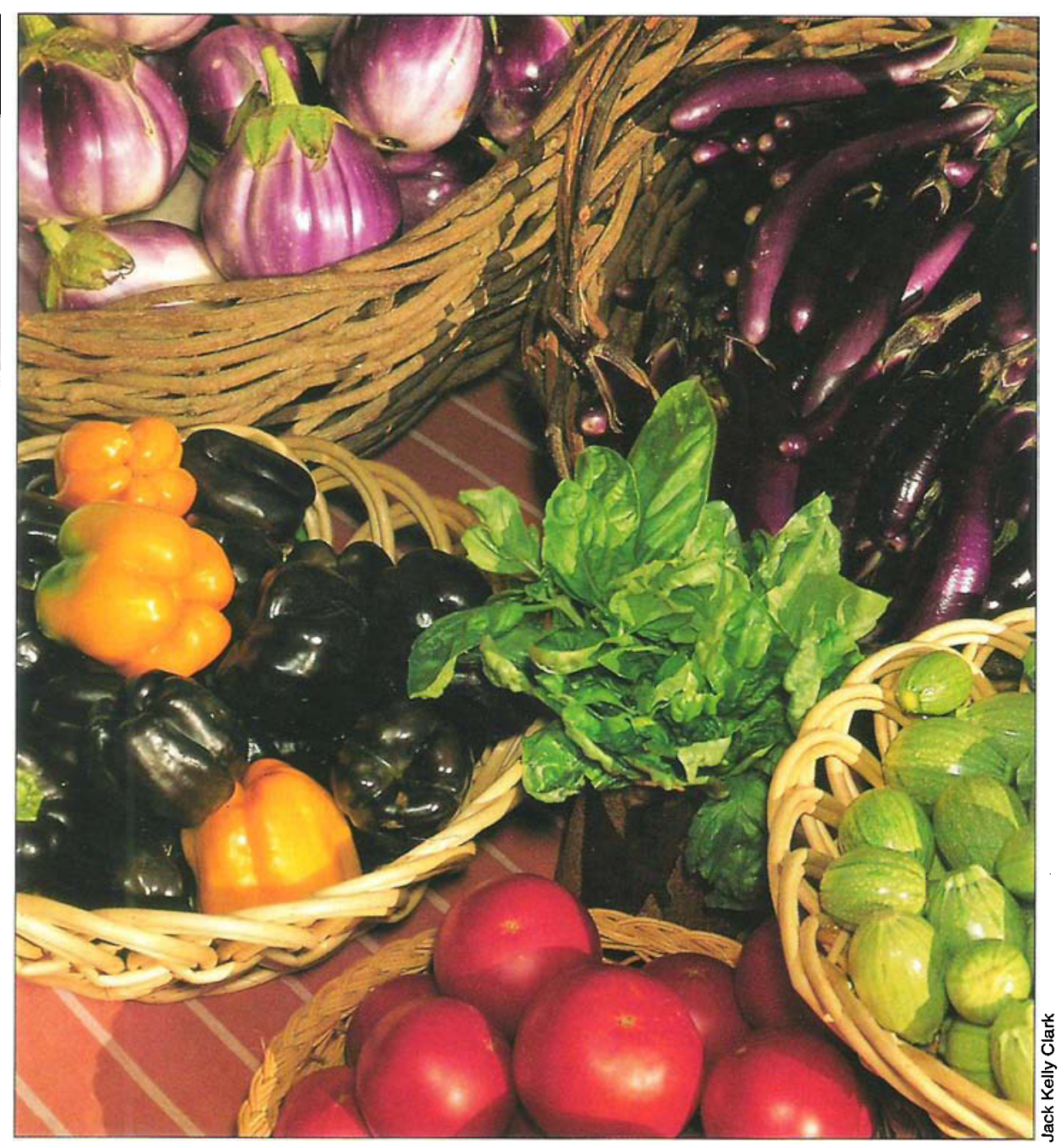

\title{
Fuji apple, radicchio, basil, walnut top specialty crop research needs
}

\author{
Stephen H. Brown $\square \quad$ Louie H. Valenzuela
}

\section{Growers and distributors list 130 specialty crops they think need re- search. Heading the list: Fuji apple, radicchio, basil, and walnut.}

Over the last two decades, many California-grown crops that were once considered exotic or "specialty" have become commonplace in supermarkets. Many of these crops have received little or no research attention. A statewide survey of growers and handlers was conducted in 1989 with these objectives: to determine specific research needs and to plan future University studies of specialty crops.

\section{The survey}

A questionnaire was sent to 500 growers and distributors (handlers) throughout California. We received 69 responses, a response rate of $14 \%$. Specialty crops were identified for the respondents as unusual varieties of common crops as well as ethnic and exotic crops.

Growers and distributors were asked to list one or more specialty fruit, vegetable, herb, and nut crops needing research attention. They were asked to identify up to five commodities in each category. For each commodity listed, growers were asked to choose from a list of possible ar- 